\title{
Mobile Usage, Shopping Behaviour and Study Habit as Contributing Factor to Depression, Anxiety and Stress: A Review
}

Nadzirah Mawi, Hazalizah Hamzah, Asma Perveen

To Link this Article: http://dx.doi.org/10.6007/IJARBSS/v10-i9/7824

DOI:10.6007/IJARBSS/v10-i9/7824

Received: 25 June 2020, Revised: 27 July 2020, Accepted: 29 August 2020

Published Online: 30 September 2020

In-Text Citation: (Mawi, Hamzah, \& Perveen, 2020)

To Cite this Article: Mawi, N., Hamzah, H., \& Perveen, A. (2020). Mobile Usage, Shopping Behaviour and Study Habit as Contributing Factor to Depression, Anxiety and Stress: A Review. International Journal of Academic Research in Business and Social Sciences. 10(9), 439-445.

\section{Copyright: (C) 2020 The Author(s)}

Published by Human Resource Management Academic Research Society (www.hrmars.com)

This article is published under the Creative Commons Attribution (CC BY 4.0) license. Anyone may reproduce, distribute, translate and create derivative works of this article (for both commercial and non-commercial purposes), subject to full attribution to the original publication and authors. The full terms of this license may be seen at: http://creativecommons.org/licences/by/4.0/legalcode

\section{Vol. 10, No. 9, 2020, Pg. 439 - 445}




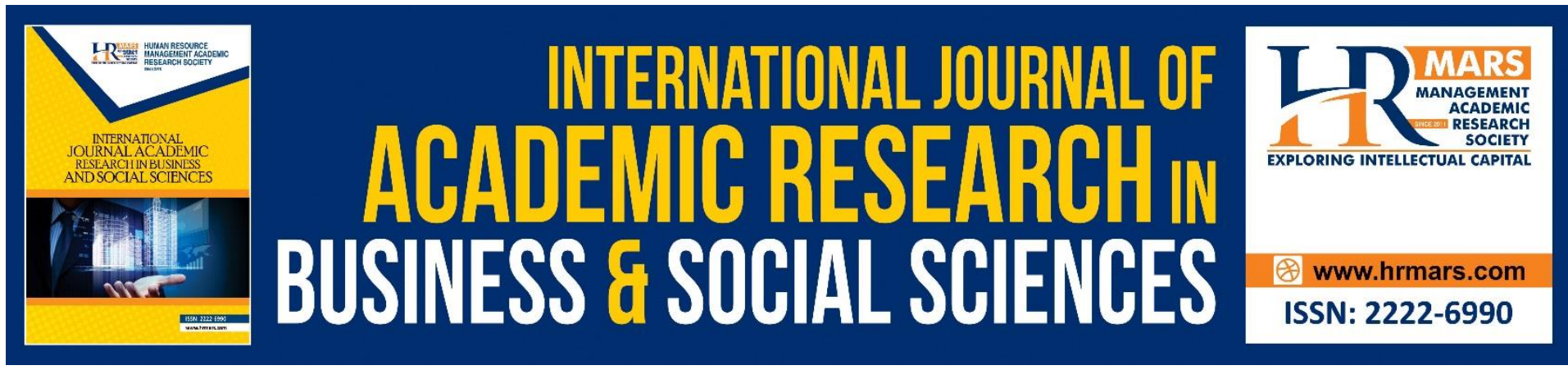

\title{
Mobile Usage, Shopping Behaviour and Study Habit as Contributing Factor to Depression, Anxiety and Stress: A Review
}

\author{
${ }^{1}$ Nadzirah Mawi, ${ }^{2}$ Hazalizah Hamzah, ${ }^{3}$ Asma Perveen \\ Department of Psychology and Counselling, Faculty of Human Development, Sultan Idris \\ Education University, Tanjung Malim, Perak. \\ Email: ${ }^{1}$ nadzirahmawi31@gmail.com, ${ }^{2}$ hazalizah@fpm.upsi.edu.my, \\ 3asmaperveen@fpm.upsi.edu.my
}

\begin{abstract}
Many studies have been carried out relating to certain behavioral aspects with mental health issues but only a few clustered depression, anxiety and stress together. Therefore, the aim of this study was to review and summarize findings obtained relating to previous studies that have been carried out concerning how mobile usage, shopping behavior and study habit act as predictor to depression, anxiety and stress. Most of the studies outside Malaysia employed survey method and some too carried out experiment in their research. Tracing back previous research and identifying their method, multiple analyses such as correlation, multiple regression and sequential equation modeling provided researcher with information beneficial for future research. Numerous similar and contradictory results also obtained relating to this topic. This review will extend the current literature on depression, anxiety and stress by examining the underlying contributing factors to those negative emotional states. Other than that, it can provide better understanding regarding those emotional states which can lead to better academic and social life. As studies highlighting these variables are limited, a new platform for future research could be conducted particularly among university students in Malaysia.
\end{abstract}

Keywords: Mobile Usage, Shopping Behavior, Study Habit, Mental Health.

\section{Introduction}

Some students may find transition to university life to be overwhelmed. Though they might have been prepared for the reality of university life which involve workload, evaluation and independent learning (Blair, 2016), the emotional process and the students' adjustment may differ from one to another. Juggling multiple things at once is common as during this period, student's life will involve studying, attending lectures and group discussion, completing assignments, engaging in club activities and programs, hanging out with friends and many more. Other than that, in university, students are taught to be more independent and responsible in their action as there are no teachers or parents to monitor their behaviour. A student will physically getting mature and becoming psychologically unstable during this 
stage. However as being detached and away from family members and friends, university students might replace those changes with various coping strategies.

Some might find ease in mingling with supporting new friends, some might choose to focus in studying, and others might spend time shopping and doing all sorts of activities. The important of adjustment is evident in meta-analysis finding by Crede and Niehorster (2012) as it enables a student to perform well in academic, to obtain a degree and to view the university experience as positive. Not only these is experienced by freshman, sophomore and senior students are not exceptional. Inability to deal with the emotional changes could be one of the factors that lead to students' psychological breakdown. Other than that, mental health issues among students can also be related to other outer factors. It is revealed in a study by Mas Abdul Rashid, Othman \& Ibrahim (2017) whom stated that financial difficulty is one of the major factors that lead to mental health problems among students, other than workload deadlines, requirement to maintain academic grades and personal problems.

Not only mental health issue applies to first-year university students, sophomore and even senior students also susceptible to the issue. Thus, it leads to research questions which are:

1. Which factors are associated to depression?

2. Which factors are associated to anxiety?

3. Which factors are associated to stress?

Since the area of mental health is wide and varied, most of the problems are easily recognizable. But unfortunately, some are them have very subtle symptoms thus making them hard to be detected. Since that is the case, when it is subtle, people tend to look away the significance of each symptom. A lot of people are unable to identify specific disorders or different types of psychological distress (Jorm, 2000). Some that has been identified are on biological factors but mostly are on social factors which are very much indeed very direct towards individuals' way of life. Thus here, this research gap would be the behavioural factors of individuals specifically students which can affect their psychological states.

Since there are a lot of behavioural aspects that can be taken into account, this study would only focus towards three main behaviours that most of research are looking into. Hence, the aim of this study was to review and summarize findings obtained relating to previous studies that have been carried out concerning how mobile usage, shopping behavior and study habit act as predictor to depression, anxiety and stress. In particular, the objective is to highlight, rationalize and interpret the similarities and differences among the studies in term of content, methodology and their findings.

As to authors' knowledge, the combination literature involving mobile usage, shopping behaviour and study habit has not been conducted previously, thus this would be a valuable contribution to the field. Combination of predictors may lead to certain emotional and psychological reaction in an individual and not much studies have conducted such blend which could definitely give us more input regarding each factor. Here, a review of studies may give an insight of how each factor, combination of two factors and even three factors would either summing up to same conclusion or not. Such result would reveal and give more prominent evidence of how much each result may differ from each year even from different type of population. On top of that, this paper contributes to suggestions that can be considered and used in future study. 


\section{Methodology}

The studies in this review are found through database Google Scholar and Ebscohost. A number of 26 studies are found relating to mobile usage, 15 studies relating to shopping behavior and 9 studies relating to study habit. They were screened from April 2018 to January 2019. The tables in this review would be emphasizing it's so-called independent variables which are mobile usage, shopping behaviour and study habit. There are a few inclusion criteria of the studies included in this review. Since there are three independent variables, the tables to be constructed will be three as well. Besides that, though this review focus on three dependent variables which are depression, anxiety and stress, some studies might focus only single variable such as solely on either depression, anxiety or stress. Some might be combining any two of them, such as depression and anxiety, or depression and stress or anxiety and stress. Nevertheless, all of them are included in this review to maximize the findings of the study.

Besides that, a few studies might not be using the same term stated in this review. An example that can be referred to is instead of mobile usage, some studies might be using the term smartphone addiction, cellphone use and mobile phones usage. However, since they convey the same meaning, they are all included in the review. Similar processes were undergone by the term shopping behaviour since most studies preferred to use the term compulsive buying and impulsive buying when it involved shopping behaviour. The table will be organized chronologically starting from the earliest to latest study carried out relating to the variables mentioned in order to trace the development of the studies over time. It will be made up of independent variables as its focus, and other section would be stating its authors, and its results. Not all studies will be explained in detail, as only a few will be pinpointed due to its importance.

In short, the table will be constructed and divided into the key elements of the studies namely name of the author of the article together with year of publication, method, sampling and lastly the findings of the study. Since there are three independent variables being studied, thus, three independent tables are laid.

\section{Results}

A breakdown of the results by study can be seen in Table 1. Another inclusion criterion for the studies in this review is all of them are from year 2010 to 2019. For mobile usage, the study begins with one conducted by Thomee, Harenstam and Hagberg (2011). This publication creates a stream of papers up to 2019 ranging from all different types of samples such as youths, teenagers and even households. From the Table, it is shown that most of the studies are focusing on students. Most of the studies found out that the use of mobile phone is either significantly correlated with depression, anxiety of stress. However, Harwood, Dooley, Scott \& Joiner (2014) revealed that the nature of the relationship a person has with their smartdevice that is predictive of depression and stress, rather than the extent of use. On top of that Tamura, Nishida, Tsuji \& Sakakibara (2017) discovered that other than duration of mobile phone usage, how it is used also lead to mental health issue. The use of social network services and online chats respectively, was associated with a higher risk of depression than the use for internet searching, playing games or viewing videos.

A group of psychiatric researchers in Brazil have defined a new disorder called Nomophobia, which describes people's dependencies on mobile devices (King et al., 2013), characterized by feeling of anxiety or discomfort caused by being out of contact with a wireless mobile devices or computer, or a fear of remaining out of touch with technology, especially 
among those who exhibit social phobias. A few studies suggested that there is positive correlation exists between smartphone use and stress (Vahedi \& Saiphoo, 2018; Vasanthakumaran, 2018). The effect could be direct and also non-direct. This is because there is an association of mobile phone usage with sleep quality and academic performance (Sowmiya, Vidya, Lakshmi \& William, 2017; Thomee, 2018). This indicates that the use of mobile usage may disrupt sleep quality of an individual. Without good sleep quality, academic performance will decline and lastly causing one to have stress. There are also studies that reveal the excessive use of mobile usage which will then results to mobile addiction have significant correlation with academic stress (Thomas, 2016). Students particularly, will have reduced sleep duration or sleep quality, lower down the productivity and lastly causing stress. Not only that this happen among human being, a clinical study using rats as revealed that long term exposure to cell phone radiation enhances serum cortisol level which may indicate the existing of stress in animals (Ahmadi Tameh, Ahmadi \& Gohari, 2014). Though the usage of mobile phone is also proven in association with reduced stress (Toda, Ezoe \& Takeshita, 2014), this may be due to how one's perceive the role of mobile usage in one's life.

In term of shopping behavior, only 15 studies were found that relate it to depression, anxiety and stress. Inclusion of impulsive and compulsive buying discussion will be able to generate wider scope of literature. Compulsive buyers are obsessed with buying, and they display repetitive, irresistible, and overpowering urges to purchase goods that are frequently useless and/or unused items (Weinstein, Maraz, Griffiths, Lejoyeux \& Demetrovics, 2016). The onset for this disorder is in late adolescence to early adulthood, and female-to-male ratio may be 9:1 (Sharma, Narang, Rajender \& Bhatia, 2009). Most authors chose to conduct survey relating to this topic, except for two which conducted experiment in their study, which was by Kyrios, McQueen and Moulding (2013); Durante \& Laran (2016). Another one which was by Muller, Mitchell, Crosby, Cao, Johnson, Claes and de Zwaan (2012) took it to another level which combine survey and experiment in their study.

Most of studies found there is significant correlation between shopping behavior with depression, anxiety and stress, and the relationship is bi-directional. Hama (2001) suggested that a certain amount of expenditure was needed for stress release, but a high one did not relieve stress, and the finding was later supported by Durante and Laran (2016) which stated that the effect of stress does not solely lead to saving and decreased in spending. It might also result in increased in spending depending on how an individual perceive the stress. Even that so, Albrecht, Hattula \& Lehmann (2017) suggesting that shopping is sometimes a source of stress, leading to avoidance coping behaviour by consumers. In term of impulsiveness, it is shown that people who faced high interpersonal influence depicted more impulsive buying due to the stress generated by the psychosocial stressor, but consumers with high emotional intelligence were less prone to stress which, in turn, led to low impulsive buying (Zia \& Shahzad, 2017). On top of that, findings indicated that compulsive buyers have been reported as having more depressive symptoms (Otero-López \& Villardefrancos, 2014; Bani-Rshaid \& Alghraibeh; 2017), and vice versa too where depression and materialism are having a significant impact to compulsive buying behaviour (Omar, Wel, Alam, Nazri, 2015). 
INTERNATIONAL JOURNAL OF ACADEMIC RESEARCH IN BUSINESS AND SOCIAL SCIENCES

Vol. 10, No. 9, 2020, E-ISSN: 2222-6990 @ 2020 HRMARS

Studies Relating to Mobile Usage from 2010-2019

\begin{tabular}{llll}
\hline Author (Year) & Sample & Method & Result \\
\hline Thomee, Harenstam \& Hagberg & 4156 young adults & Survey & Other than depression, excessive mobile
\end{tabular}

Augner \& Hacker (2012)

Hong, Chiu \& Huang (2012)

Lepp, Barkley\& Karpinski (2013)

Harwood, Dooley, Scott \& Joiner (2014)

Smetaniuk (2014)
196 young adults

Survey

269 Taiwanese female university students

Survey

536 undergraduate students

Survey

274 people in which 186

Survey were students, and others are either employed, unemployed or retired

Study 1 (301 students), Study 2 (362 non-students) phone usage was linked to the experience of stress and sleep disturbances for women.

Low emotional stability, chronic stress, and depression have a correlation with phone usage.

Social extraversion and anxiety have positive effects on mobile phone addiction and self-esteem has negative effects on mobile phone addiction.

Cell phone use/texting was negatively related to GPA and positively related to anxiety.

Smart-device use was not significantly associated with depression, anxiety or stress, indicating that the nature of the relationship a person has with their smartdevice that is predictive of depression and stress, rather than the extent of use.

The results from Study 1 and Study 2 indicate that 10 to $25 \%$ of the participants tested exhibited problematic cell phone usage. Additionally, age, depression, extraversion, and low impulse control are the most suitable predictors for problem use. 
INTERNATIONAL JOURNAL OF ACADEMIC RESEARCH IN BUSINESS AND SOCIAL SCIENCES Vol. 10, No. 9, 2020, E-ISSN: 2222-6990 @ 2020 HRMARS

Toda, Ezoe \& Takeshita (2014)

139 medical university students

Survey

\section{9 university students \\ Survey}

(2015)

Kim, Lee \& Choi (2015)

Kim, Seo \& David (2015)

Lemola, Perkinson-Gloor, Brand, Dewald, Kaufmann \& Grob

(2015)

Poorakbaran (2015)

Schoeni, Roser \& Roosli (2015)

351 Grade 6

Survey

elementary school students

395 adults recruited through the Amazon Mechanical Turk, a crowdsourcing Internet marketplace used for posting work for pay.

362 adolescents

Survey

Survey

209 young adults

Survey

439 adolescents

Survey
The intensity and type of mobile phone use may be associated with stress coping, particularly planful problem solving strategy.

Depression, anxiety and sleep quality may be associated with smartphone overuse.

Mobile phone use was positively correlated with anxiety, and it was negatively correlated with parental childraising attitudes.

Depressed people may rely on mobile phone to alleviate their negative feelings and spend more time on communication activities via mobile phone, which in turn can deteriorate into problematic use of mobile phone (PUMP).

Sleep disturbance partially mediated the relationship between electronic media use at night and depressive symptoms, indicating that using electronic media at night might influence sleeping process and lastly causing the emergence of depressive symptoms.

The anxiety scores were higher in use of cell phone and the anxiety and stress scores were higher in use of internet, and the depression and stress scores were higher in use of satellite significantly.

Mobile phone overuse for social network services and online chats may contribute 
Van Deursen, Bolle, Hegner \& Kommers (2015)

Wang, Wang, Gaskin \& Wang (2015)

Jeong, Kim, Yum, Hwang (2016)

Samaha \& Hawi (2016)

Boumosleh \& Jaalouk (2017)

Hawi \& Samaha (2017)
386 randomly selected individuals

Survey

Using a sample of 600 typical smartphone users

(Chinese college students)
Survey

$\begin{array}{lr}944 \text { respondents were } & \text { Survey } \\ \text { recruited from } 20 \\ \text { elementary schools in South } \\ \text { Korea } \\ 300 \text { university students } & \text { Survey } \\ \begin{array}{l}688 \text { undergraduate } \\ \text { university students }\end{array} & \text { Survey }\end{array}$

381 university students Survey to depression than the use for internet searching, playing games or viewing videos.

Habitual phone use is a significant factor that lead to addictive smartphone behaviour. Besides that, social stress and failure of self-regulation positively affecting addictive smartphone behaviour but emotional intelligence did not.

Perceived stress moderates the relationship between entertainment motivation and problematic smartphone use, perceived stress moderated the relationship between entertainment motivation and problematic use also among users scoring low on problematic smartphone use.

Self-control was a negative predictor, whereas stress was a positive predictor of smartphone addiction.

Smartphone addiction risk was positively related to perceived stress.

Depression and anxiety were found to be independent factor to smartphone addiction, after adjustment for confounders

Undergraduate students who had smartphone addiction demonstrated greater odds of having high anxiety 

northern Taiwan

92 households selected by Survey

Pearson, Mack \& Namanya (2017)

Reinecke et al. (2017)

Tamura, Nishida, Tsuji \& Sakakibara (2017) simple

random sampling from

village rosters

1,557 German households

Survey

295 students from $1^{\text {st }}$ to $3^{\text {rd }}$ Survey grades of high school in Japan compared to those who were not addicted, and students who had high anxiety exhibited greater odds of having clinically significant problems in their family relations. Nevertheless, path analysis showed that anxiety mediated a positive relationship between smartphone addiction and problematic family relations.

University students' love-affair stress and academic stress positively influence smart phone addiction, and their stress of interpersonal relationship, stress of selfcareer, family life stress, and time management and issues significantly influence their life satisfaction. Households which own mobile phone had higher levels of wealth on average but it did not become the sole cause of mobile phone ownership and mental well-being. Communication load was positively related to perceived stress and had an indirect impact on depression and anxiety. Mobile phone use of $2 \mathrm{~h}$ or more per day for social network services and online chats respectively, was associated with a higher risk of depression. Moreover, mobile phone overuse for social network services and online chats may contribute more to depression than the use for 
Gao et al. (2018)

Visnjic et al. (2018)

Vasanthakumaran, T. (2018).
1105 college students

Survey

785 students at two

Survey distinguished universities in Serbia and Italy

120 participants both studying and working in the medical profession internet searching, playing games or viewing videos.

The level of alexithymia was significantly correlated with depression, anxiety, stress and mobile phone addiction. It also acted as a predictor on mobile phone addiction. Depression, anxiety or stress on the other hand had partially mediating effects between alexithymia and mobile phone addiction. Alexithymia not only directly had a positively impact on mobile phone addiction, but both also had an indirect effect on mobile phone addiction through depression, anxiety or stress.

Mental health problems are dependent on the way and the intensity of using the mobile phones. For instance, anxiety symptoms are somewhat more present in younger students in those who send more text messages and browse the internet less frequently. Stress in contrast is being experienced more by students who make fewer calls a day as well in those who spend more time talking on the mobile phone per day.

Statistically significant correlation is seen between mobile phone usage and stress, sleep disturbance and symptoms of depression. 
INTERNATIONAL JOURNAL OF ACADEMIC RESEARCH IN BUSINESS AND SOCIAL SCIENCES

Vol. 10, No. 9, 2020, E-ISSN: 2222-6990 @ 2020 HRMARS

Tangmunkongvorakul et al. $\quad 800$ university students Survey (2019)

Students with excessive use of smartphones had lower scores the psychological well-being than those who did not use smartphone excessively.

Studies Relating to Shopping Behaviour from 2010-2019

\begin{tabular}{|c|c|c|c|}
\hline Author (Year & Sample & Method & Result \\
\hline Ergin (2010) & $\begin{array}{l}314 \text { respondents, who are } \\
\text { visitors of shopping malls in } \\
\text { Ankara }\end{array}$ & Survey & $\begin{array}{l}\text { Shopping was found as an en route to } \\
\text { escapism which provides an outlet for } \\
\text { psychological compensation where it aids } \\
\text { to reduce the anxiety and stress in their } \\
\text { everyday lives. }\end{array}$ \\
\hline $\begin{array}{l}\text { Davenport, Houston, \& Griffiths } \\
\text { (2012) }\end{array}$ & 134 women & Survey & $\begin{array}{l}\text { Reward sensitivity and cognitive anxiety } \\
\text { were positively related to excessive eating } \\
\text { and compulsive buying, as was impulsivity } \\
\text { to compulsive buying. Somatic anxiety and } \\
\text { social desirability were negatively related } \\
\text { to compulsive buying. }\end{array}$ \\
\hline $\begin{array}{l}\text { Muller, Mitchell, Crosby, Cao, } \\
\text { Johnson, Claes \& de Zwaan (2012) }\end{array}$ & $\begin{array}{l}25 \text { participants having } \\
\text { diagnostic criteria of } C B\end{array}$ & Survey and experiment & $\begin{array}{l}\text { The comparison of mood and the impact } \\
\text { of daily stress on days on which } \\
\text { compulsive buying occurred to those days } \\
\text { on which compulsive buying episodes did } \\
\text { not occur did not reveal any significant } \\
\text { differences. }\end{array}$ \\
\hline Roberts \& Roberts (2012) & $\begin{array}{l}82 \text { seventh graders ranging } \\
\text { in age from } 12 \text { to } 13 \text { years } \\
\text { of age. }\end{array}$ & Survey & $\begin{array}{l}\text { Higher levels of stress led to higher levels } \\
\text { of compulsive buying. }\end{array}$ \\
\hline $\begin{array}{l}\text { Kyrios, McQueen \& Moulding } \\
\text { (2013) }\end{array}$ & $\begin{array}{l}18 \text { compulsive buyers and } \\
17 \text { non-clinical controls }\end{array}$ & Experiment & $\begin{array}{l}\text { In study } 1 \text { the memory-facilitating effect } \\
\text { of depressed mood was evident among } \\
\text { control participants and absent among }\end{array}$ \\
\hline
\end{tabular}




\section{Otero-López \& Villardefrancos}

\section{(2014)}

Omar, Wel, Alam \& Nazri (2015)

Singh \& Nayak (2015)

Weinstein, Mezig, Mizrachi \& Lejoyeux, (2015)

Yuksel \& Eroglu (2015)

\section{9 inhabitants in Galicia \\ Survey}

177 university students located at Klang Valley

246 adolescents aged from 15 to 18 years old

\section{0 partcipants who}

shopped

regularly on the internet

for at least twice a week.

892 consumers in three

cities in the West side of

Turkey
Survey

Survey

Survey

Survey compulsive buyers. In study 2, compulsive buyers showed a lesser association of undesirable objects with positive emotional concepts than did non-clinical controls, and compulsive buyers were found to more strongly associate all consumer items with emotional concepts than with concepts of function.

Compulsive buyers have been reported as having more depressive symptoms.

Depression and materialism are having a significant impact to compulsive buying behaviour.

Adolescents practicing compulsive buying behaviour as a way to cope with heightened levels of stress due to familial and non-familial factors.

The results of this study support existing evidence for an association between compulsive buying and anxiety.

Personal factors namely materialism, selfesteem and mental disorders, and relating them to advertising and compulsive buying tendency (CBT) in the context of consumer culture. The authors have listed three types of mental disorders in the study which are depression, anxiety and stress 
INTERNATIONAL JOURNAL OF ACADEMIC RESEARCH IN BUSINESS AND SOCIAL SCIENCES Vol. 10, No. 9, 2020, E-ISSN: 2222-6990 @ 2020 HRMARS

$\begin{array}{lll}\text { Darrat, Darrat \& Amyx (2016) } & \begin{array}{l}143 \text { undergraduate Survey } \\ \text { students }\end{array}\end{array}$

Durante \& Laran (2016)

Iqbal \& Aslam (2016)

Bani-Rshaid \& Alghraibeh (2017)

\section{Experiment 1 (230}

students), Experiment 2 (70

participants)

430 university students within the age range of 18 to 24 years from five universities of Islamabad and Rawalpindi.

744 citizens who visited the Survey city's shopping centers
Impulse buying is related positively to consumer anxiety whereas escapism is related negatively to compulsive buying. On top of that, consumer anxiety is related positively to compulsive buying and consumer escapism. Thus, this underlines that not only shopping behaviour affects anxiety but anxiety also affects shopping behaviour as well.

Stress led consumers to save rather than spend money. However, when there is a need to spend money, they chose to use on necessities rather than nonnecessities, and this effect was mediated by a willingness to restore control.

There is no significant relationship between depression and compulsive buying.

There is significant positive relationship between compulsive buying disorder and depression symptoms. 
INTERNATIONAL JOURNAL OF ACADEMIC RESEARCH IN BUSINESS AND SOCIAL SCIENCES Vol. 10, No. 9, 2020, E-ISSN: 2222-6990 @ 2020 HRMARS

Moon \& Attiq (2018)
895 fashion clothing consumers from shopping malls of different cities in

Pakistan
Survey

Not only the authors found out that anxiety positively influenced compulsive buying, depression and stress also works the same way. Self-esteem had a significant negative influence whereas materialism had a significant positive influence on compulsive buying. The result of the study indicated that stress is the strongest antecedent of compulsive buying and compulsive buying provides consumers with huge positive feelings because of shopping in a mall.

\section{Studies Relating to Study Habit from 2011-2019}

\begin{tabular}{|c|c|c|c|}
\hline Author (Year) & Sample & Method & Result \\
\hline $\begin{array}{l}\text { Bahrami, Rajaeepour, Rizi, } \\
\text { Zahmatkesh \& Nematolahi (2011) }\end{array}$ & $\begin{array}{l}100 \text { students of MSc and } \\
\text { PhD students in the } \\
\text { second semester ( } 2008- \\
2009 \text { ) of Isfahan University } \\
\text { of Medical Sciences }\end{array}$ & Survey & $\begin{array}{l}\text { There is a significant and negative } \\
\text { relationship between studying and } \\
\text { depression, and happiness and depression }\end{array}$ \\
\hline Udeani (2012) & $\begin{array}{l}124 \text { fifth year science } \\
\text { students in one co- } \\
\text { educational secondary } \\
\text { school in Akoka, } \\
\text { Lagos State of Nigeria }\end{array}$ & Survey & $\begin{array}{l}\text { The relationship among study habits, } \\
\text { facilitating anxiety and debilitating anxiety } \\
\text { was not significant. }\end{array}$ \\
\hline Lawrence (2014) & $\begin{array}{l}300 \text { students from } 10 \\
\text { higher secondary schools }\end{array}$ & Survey & $\begin{array}{l}\text { There was no significant relationship } \\
\text { between study habits and test anxiety of } \\
\text { higher secondary students. }\end{array}$ \\
\hline
\end{tabular}


INTERNATIONAL JOURNAL OF ACADEMIC RESEARCH IN BUSINESS AND SOCIAL SCIENCES Vol. 10, No. 9, 2020, E-ISSN: 2222-6990 @ 2020 HRMARS

Kumaravelan \& Selvaraju (2015) 1010 higher secondary Survey students

Rao \& Reddy (2015)

Kaur \& Kaur (2016)

Numan \& Hasan (2017)

AlFaris et al. (2018)

Gilavand (2018)
400 teacher trainees

Survey

100

rural adolescents and 100

were urban adolescents

from Ludhiana district

180 undergraduate

students

372 students attending the College of Medicine, King

Saud University, Riyadh,

Kingdom of Saudi Arabia

170 general medical

students from Ahvaz

Jundishapur University of

Medical Sciences
The findings revealed that the study habits and mental health in relation to their examination stress of Vellore higher secondary students were significantly correlated.

It was shown that teacher trainees with low academic stress, good mental health and good study habits are better in their academic achievement and vice versa.

There is a significant relationship between the two variables of the study implying that academic stress might affect study habits and vice versa

Not only study habits have a significant effect on general anxiety, it also affected test anxiety and academic achievement. Poor study skills were found to correlate with higher depressive symptoms.

There was a significant inverse correlation between the level of test anxiety and the study habits by medical students. 
INTERNATIONAL JOURNAL OF ACADEMIC RESEARCH IN BUSINESS AND SOCIAL SCIENCES Vol. 10, No. 9, 2020, E-ISSN: 2222-6990 @ 2020 HRMARS

Fewer studies are found relating to study habit. However, most studies found similar findings in which study habit affect depression, anxiety and stress. The term study habit is most commonly associated to students, and in fact all of the studies use students as their samples except for one study by Rao \& Reddy (2015) which use teacher trainees as their samples. There is bi-directional relationship between these variables too, in which Kaur \& Kaur (2016) stated that there is a significant relationship between academic stress and study habit implying that academic stress might affect study habits and vice versa. Academic stress is not an unfamiliar experience among students. It is described as a student's interpretation of the present demands, challenges and treats in the academic environment in relation to available personal resources for coping (Siegel, 2008). Rather than general stress, academic stress is also included in this discussion as it is more specific and more relatable to students.

Level of stress also affects study habit, as Sohail (2013) stated that an optimal level of stress enhances learning while excess of stress can cause health problems. Prior studies also shown the reverse relationship between study habit and anxiety, where anxiety can have a debilitating effect on academic performance which is related to study habit as well (Macher, Paechter, Papousek, \& Ruggeri, 2012). Some studies also discover the relationship between academic anxiety with study habits, reflecting in a study by Desiderato and Koskinen (1969), where the authors stated that differences in level of academic anxiety were also related to differences in study habits, and these were, in turn, related to GPA. To author's knowledge there are not much studies carried out on how study habits affect anxiety. Most found were either on stress or depression.

\section{Conclusion}

Compared to shopping behavior and study habit, more studies were found relating to mobile usage. This may be because of how time flies so fast that new era has acknowledging how importance the technology and devices are as they connect one to another. Mobile usage has caused sleep disturbance and also mobile phone addiction, and last but not least leading to depression, anxiety and stress. Though some of them ends up to different findings, most of them revealed that there is significant relation between mobile usage, shopping behavior and study habit with depression, anxiety and stress. The relationship is vice versa. Most of the studies also used survey in the studies, and a combination of method might be better as it reduces the disadvantages of self-report responses in survey. Since in Malaysia, only a few studies were found relating to this issue, more studies are needed in order to found out how it is generalizable to other population. On top of that, a combination of method involving qualitative and quantitative research method may uncover new findings relating to mobile usage, shopping behaviour and study habit which would definitely benefits everyone.

\section{References}

Tameh, A., Ahmadi, R., \& Gohari, A. (2014, December). Long term exposure to cell phone radiation and stress. In International Conference on Earth, Environment and Life Sciences, Dubai.

Albrecht, C. M., Hattula, S., \& Lehmann, D. R. (2017). The relationship between consumer shopping stress and purchase abandonment in task-oriented and recreation-oriented consumers. Journal of the Academy of Marketing Science, 45(5), 720-740. 
INTERNATIONAL JOURNAL OF ACADEMIC RESEARCH IN BUSINESS AND SOCIAL SCIENCES

Vol. 10, No. 9, 2020, E-ISSN: 2222-6990 @ 2020 HRMARS

Augner, C., \& Hacker, G. W. (2012). Associations between problematic mobile phone use and psychological parameters in young adults. International Journal of Public Health, 57(2), 437441.

Bahrami, S., Rajaeepour, S., Rizi, H. A., Zahmatkesh, M., \& Nematolahi, Z. (2011). The relationship between students' study habits, happiness and depression. Iranian Journal of Nursing and Midwifery Research, 16(3), 217-221.

Bani-Rshaid, A. M., \& Alghraibeh, A. M. (2017). Relationship between compulsive buying and depressive symptoms among males and females. Journal of Obsessive-Compulsive and Related Disorders, 14, 47-50.

Boumosleh, J. M., \& Jaalouk, D. (2017). Depression, anxiety, and smartphone addiction in university students-A cross sectional study. PLoS one, 12(8), e0182239.

Darrat, A. A., Darrat, M. A., \& Amyx, D. (2016). How impulse buying influences compulsive buying: The central role of consumer anxiety and escapism. Journal of Retailing and Consumer Services, 31, 103-108.

Davenport, K., Houston, J. E., \& Griffiths, M. D. (2012). Excessive eating and compulsive buying behaviours in women: An empirical pilot study examining reward sensitivity, anxiety, impulsivity, self-esteem and social desirability. International Journal of Mental Health and Addiction, 10(4), 474-489.

Demirci, K., Akgonul, M., \& Akpinar, A. (2015). Relationship of smartphone use severity with sleep quality, depression, and anxiety in university students. Journal of Behavioral Addictions, 4(2), 85-92.

Desiderato, O., \& Koskinen, P. (1969). Anxiety, study habits, and academic achievement. Journal of Counselling Psychology, 16(2, Pt.1), 162-165.

Durante, K. M., \& Laran, J. (2016). The effect of stress on consumer saving and spending. Journal of Marketing Research, 53(5), 814-828.

Ergin, E. A. (2010). Compulsive buying behavior tendencies: The case of Turkish consumers. African Journal of Business Management, 4(3), 333-338.

Gao, T., Li, J., Zhang, H., Gao, J., Kong, Y., Hu, Y. et al. (2018). The influence of alexithymia on mobile phone addiction: The role of depression, anxiety and stress. Journal of Affective Disorders, 225, 761-766.

Gilavand, A. (2018). Evaluation of study habits among general medical students and its relation with test anxiety in Ahvaz Jundishapur University of Medical Sciences, Southwest of Iran. Journal of Research in Medical and Dental Science, 6(5), 240-245.

Hama, Y. (2001). Shopping as a coping behaviour for stress. Japanese Psychological Research, 43(4), 218-224.

Harwood, J., Dooley, J. J., Scott, A. J., \& Joiner, R. (2014). Constantly connected-The effects of smartdevices on mental health. Computers in Human Behavior, 34, 267-272.

Hawi, N. S., \& Samaha, M. (2017). Relationships among smartphone addiction, anxiety, and family relations. Behaviour \& Information Technology, 36(10), 1046-1052.

Hong, F., Chiu, S., \& Huang, D. (2012). A model of the relationship between psychological characteristics, mobile phone addiction and use of mobile phones by Taiwanese university female students. Computers in Human Behavior, 28, 2152-2159.

Iqbal, N., \& Aslam, N. (2016). Materialism, depression, and compulsive buying among university students. The International Journal of Indian Psychology, 3(2), 91-102. 
INTERNATIONAL JOURNAL OF ACADEMIC RESEARCH IN BUSINESS AND SOCIAL SCIENCES

Vol. 10, No. 9, 2020, E-ISSN: 2222-6990 @ 2020 HRMARS

Jeong, S. H., Kim, H., Yum, J. Y., \& Hwang, Y. (2016). What type of content are smartphone users addicted to?: SNS vs. games. Computers in Human Behavior, 54, 10-17.

Kaur, J., \& Kaur, N. (2016). Academic stress of adolescents in relation to study habits. International Multidisciplinary E-Journal, 5(2), 306-313.

Kim, R., Lee, K. J., \& Choi, Y. J. (2015). Mobile phone overuse among elementary school students in Korea: Factors associated with mobile phone use as a behavior addiction. Journal of Addictions Nursing, 26(2), 81-85.

Kim, J. H., Seo, M., \& David, P. (2015). Alleviating depression only to become problematic mobile phone users: Can face-to-face communication be the antidote?. Computers in Human Behavior, 51, 440-447.

King, A. L. S., Valença, A. M., Silva, A. C. O., Baczynski, T., Carvalho, M. R., \& Nardi, A. E. (2013). Nomophobia: Dependency on virtual environments or social phobia? Computers in Human Behavior, 29, 140-144.

Kuang-Tsan, C., \& Fu-Yuan, H. (2017). Study on relationship among university students' life stress, smart mobile phone addiction, and life satisfaction. Journal of Adult Development, 24(2), 109118.

Kumaravelan, M. E., \& Selvaraju, R. (2015). Study habits and mental health in relation to their examination stress of Vellore higher secondary students: A gender wise analysis. International Journal of Advanced Research, 3(8), 721-726.

Kyrios, M., McQueen, P., \& Moulding, R. (2013). Experimental analysis of the relationship between depressed mood and compulsive buying. Journal of Behavior Therapy and Experimental Psychiatry, 44(2), 194-200.

Lawrence, A. A. (2014). Relationship between study habits and test anxiety of higher secondary students. Online Submission, 3(6), 1-9.

Lemola, S., Perkinson-Gloor, N., Brand, S., Dewald-Kaufmann, J. F., \& Grob, A. (2015). Adolescents' electronic media use at night, sleep disturbance, and depressive symptoms in the smartphone age. Journal of Youth and Adolescence, 44(2), 405-418.

Lepp, A., Barkley, J. E., \& Karpinski, A. C. (2013). The relationship between cell phone use, academic performance, anxiety and satisfaction with life in college students. Computers in Human Behavior, 31, 343-350.

Macher, D., Paechter, M., Papousek, I., \& Ruggeri, K. (2012). Statistics anxiety, trait anxiety, learning behavior, and academic performance. European Journal of Psychological Education, 27, 483498.

Moon, M. A., \& Attiq, S. (2018). Compulsive buying behavior: antecedents, consequences and prevalence in shopping mall consumers of an emerging economy. Pakistan Journal of Commerce and Social Sciences (PJCSS), 12(2), 548-570.

Muller, A., Mitchell, J. E., Crosby, R. D., Cao, L., Johnson, J., Claes, L., \& de Zwaan, M. (2012). Mood states preceding and following compulsive buying episodes: an ecological momentary assessment study. Psychiatry Research, 200(2-3), 575-580.

Numan, A., \& Hasan, S. S. (2017). Effect of study habits on test anxiety and academic achievement of undergraduate students. Journal of Research \& Reflections in Education (JRRE), 11(1),1-14.

Omar, N. A., Wel, C. A. C., Alam, S. S., \& Nazri, M. A. (2015). Understanding students compulsive buying apparel: An empirical study. Jurnal Personalia Pelajar, 18(2), 142-148. 
INTERNATIONAL JOURNAL OF ACADEMIC RESEARCH IN BUSINESS AND SOCIAL SCIENCES Vol. 10, No. 9, 2020, E-ISSN: 2222-6990 @ 2020 HRMARS

Otero-López, J. M., \& Villardefrancos, E. (2014). Prevalence, sociodemographic factors, psychological distress, and coping strategies related to compulsive buying: a cross sectional study in Galicia, Spain. BMC psychiatry, 14(1), 101.

Pearson, A. L., Mack, E., \& Namanya, J. (2017). Mobile phones and mental well-being: initial evidence suggesting the importance of staying connected to family in rural, remote communities in Uganda. PloS one, 12(1), e0169819.

Poorakbaran, E. (2015). Assessment of using of emerging communication tools (cell phone, internet and satellite) among young adults and its association with anxiety, depression and stress. Journal of Fundamentals of Mental Health, 17(5), 254-259.

Rao, K. V., \& Reddy, S. V. (2015). Effect of study habits, mental health and academic stress on academic achievement among teacher trainees. Indian Journal of Research, 4(6), 471-473.

Roberts, J. A., \& Roberts, C. (2012). Stress, gender and compulsive buying among early adolescents. Young Consumers, 13(2), 113-123.

Samaha, M., \& Hawi, N. S. (2016). Relationships among smartphone addiction, stress, academic performance, and satisfaction with life. Computers in Human Behavior, 57, 321-325.

Schoeni, A., Roser, K., \& Roosli, M. (2015). Symptoms and cognitive functions in adolescents in relation to mobile phone use during night. PloS one, 10(7), e0133528.

Sharma, V., Narang, K., Rajender, G., \& Bhatia, M. S. (2009). Shopaholism (Compulsive buying)-A new entity. Delhi Psychiatry Journal, 12(1), 110-113.

Siegel, J. S. (2008). The role of stress in the persistence intentions of non tradition community college students. Michigan, United States of America: Proquest Information and Learning Company.

Singh, R., \& Nayak, J. K. (2015). Life stressors and compulsive buying behaviour among adolescents in India: moderating effect of gender. South Asian Journal of Global Business Research, 4(2), 251274.

Smetaniuk, P. (2014). A preliminary investigation into the prevalence and prediction of problematic cell phone use. Journal of Behavioral Addictions, 3(1), 41-53.

Sohail, N. (2013). Stress and academic performance among medical students. Journal of the College of Physicians and Surgeons Pakistan, 23(1), 67-71.

Sowmiya, K., Vidya, D. C., Lakshmi, A., \& William, R. F. (2017). A study of mobile phone usage on sleep disturbance, stress and academic performance among medical students in Tamil Nadu. International Journal of Community Medicine and Public Health, 5(1), 365-368.

Tamura, H., Nishida, T., Tsuji, A. \& Sakakibara, H. (2017). Association between excessive use of mobile phone and insomnia and depression among Japanese adolescents. International Journal of Environmental Research and Public Health, 14(7), 701.

Tangmunkongvorakul, A., Musumari, P. M., Thongpibul, K., Srithanaviboonchai, K., Techasrivichien, T., Suguimoto, S. P. et al. (2019). Association of excessive smartphone use with psychological well-being among university students in Chiang Mai, Thailand. PloS one, 14(1), e0210294.

Thomas, D. (2016). Cell phone addiction and academic stress among university students in Thailand. In International Forum, 19(2), 80-96.

Thomee, S., Harenstam, A., \& Hagberg, M. (2011). Mobile phone use and stress, sleep disturbances, and symptoms of depression among young adults-a prospective cohortstudy. BMC Public Health, 11(1), 66. 
INTERNATIONAL JOURNAL OF ACADEMIC RESEARCH IN BUSINESS AND SOCIAL SCIENCES

Vol. 10, No. 9, 2020, E-ISSN: 2222-6990 @ 2020 HRMARS

Toda, M., Ezoe, S., \& Takeshita, T. (2014). Mobile phone use and stress-coping strategies of medical students. International Journal of Cyber Behavior, Psychology and Learning (IJCBPL), 4(4), 4146.

Udeani, U. (2012). The relationship between study habits, test anxiety and science achievement. Journal of Education and Practice, 3(8), 151-157.

Vahedi, Z., \& Saiphoo, A. (2018). The association between smartphone use, stress, and anxiety: A meta-analytic review. Stress and Health, 34(3), 347-358.

Van Deursen, A. J., Bolle, C. L., Hegner, S. M., \& Kommers, P. A. (2015). Modeling habitual and addictive smartphone behavior: The role of smartphone usage types, emotional intelligence, social stress, self-regulation, age, and gender. Computers in Human Behavior, 45, 411-420.

Vasanthakumaran, T. (2018). Mobile use, stress, sleep disturbances, and symptoms of depression in the medical profession: A cross-sectional study. International Journal of Community Medicine and Public Health, 5(8), 3345-3349.

Visnjic, A., Velickovic, V., Sokolovic, D., Stankovic, M., Mijatovic, K., Stojanovic, M. et al. (2018). Relationship between the manner of mobile phone use and depression, anxiety, and stress in university students. International Journal of Environmental Research and Public Health, 15(4), 697.

Wang, J. L., Wang, H. Z., Gaskin, J., \& Wang, L. H. (2015). The role of stress and motivation in problematic smartphone use among college students. Computers in Human Behavior, 53, 181-188.

Weinstein, A., Maraz, A., Griffiths, M. D., Lejoyeux, M., \& Demetrovics, Z. (2016). Compulsive buying - Features and characteristics of addiction. Neuropathology of Drug Addictions and Substance Misuse, 993-1007.

Weinstein, A., Mezig, H., Mizrachi, S., \& Lejoyeux, M. (2015). A study investigating the association between compulsive buying with measures of anxiety and obsessive-compulsive behavior among internet shoppers. Comprehensive Psychiatry, 57, 46-50.

Yuksel, C. A., \& Eroglu, F. (2015). The effects of personal factors and attitudes towards advertising on compulsive buying tendency. Pazarlama ve Pazarlama Araştırmaları Dergisi, 16, 43-70.

Zia, M. H., \& Shahzad, K. (2017). Interpersonal influence as psycho social stressor, stress, and impulsive buying: An empirical study in the perspective of Islamic guidelines on consumption. Journal of Islamic Business and Management, 7(2), 211-229. 